\title{
Looking Back, Moving Forward: Towards Improving Local Governments' Performance in Ghana
}

Commonwealth Journal of Local Governance Issue 13/14: November 2013

http://epress.lib.uts.edu.au/ojs/index.php/cjlg

\author{
Hamza Bukari Zakaria \\ University of Manchester, UK \\ Email:hamza.bukarizakaria@manchester.ac.uk
}

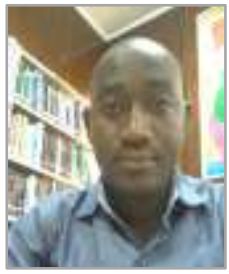

\begin{abstract}
This paper, based on a desk study, adopts a path-dependent perspective to explore how local government authorities in Ghana have attempted to institutionalise performance management at the organisational level. It questions the existing performance diagnostic framework that is used to assess local government authorities by arguing that any attempt to consolidate the prevailing 'performance assessment regime' ought to re-examine previous government initiatives that had in-built mechanisms for assessing local government performance. The prevailing system, despite its attempt to empower local authorities further promotes central government manipulation of local government administration. The paper concludes that performance assessment of local governments in Ghana will remain ineffective until local government councils genuinely serve local communities and their citizens by achieving goals and objectives that are consistent with the needs and aspirations of the latter rather than relying on annual performance assessments designed to ignore the opinions of citizens.
\end{abstract}

Keywords: Ghana, performance assessment, path dependency, decentralisation, districts

\section{Introduction}

Interest in the performance of public sector organisations has an enduring reputation in the disciplines of Public Administration and Public Management. Sufficient attention has thus been drawn to the potential role of performance management in modernising public organisations under public sector reform initiatives (Sotirakou and Zeppou 2006). Growing interests in the formulation and implementation of performance management policies in response to demands for accountability in developed countries has inspired developing and transitional countries to consider similar attempts to strengthen their own public organisations (OECD 1997;Sanderson 2001). In many jurisdictions, performance evaluation has become a standard framework designed to encourage goal-driven performance by tracking successes and or failures of organisational strategies and overall performance (Kaplan and Norton 1992; 2000).

However, considerable controversy over the determination of performance in the public sector has affected how the concept is understood, analysed and researched. There are many concerns about its ambiguity, multi-dimensionality and complexity, yet its popularity in contemporary public 
management discourse suggests that organisational performance will remain contested and evolutionary due to the nature of the public sector (Bouckaert and Halligan 2008; de Bruijn 2002; Talbot 2010; Thomas 2006), as organisations in the public sector, including local government authorities, will continue to strive towards achieving multiple goals, many of which are vague, unstable, controversial and sometimes conflicting; creating room for multi-faceted and subjective interpretations of performance (Halligan et al. 2010).

For this reason, any systemic assessment of local government performance should broadly capture real and perceived concerns and interests of multiple stakeholders since any discussion of performance is susceptible to divergent and sometimes conflicting perspectives (de Bruijn 2002: 7; Thomas 2006). Acknowledging these concerns is crucial particularly when local government authorities seek to use performance management systems to fulfil widening gaps in the demand for effective service delivery. Conversely, a growing number of studies point to a paradox of performance, whereby organisations that promote development fail to utilise performance management systems as instruments for service improvement (de LancerJulnes and Holzer 2001; Lawton et al. 2000; Meyer 2002). Inspired by these assertions, this paper contributes to the ongoing debate by looking at local government performance assessment interventions in Ghana and highlighting the importance of integrating citizens' opinions into performance assessments.

To accomplish this objective, the paper is structured as follows. The next section examines the context of local government performance and explores the theoretical literature on path dependency which is used to discuss the trajectory of local governments' performance assessment practices in Ghana. It then poses a rhetorical question to ascertain whether local government authorities are on the path towards performance improvement. The last section raises some practical concerns based on lessons from performance assessments, followed by a conclusion.

\section{The context of local government performance in Ghana}

In Ghana, previous attempts to facilitate organisational change aimed at entrusting power to people at the local level woefully failed to provide workable improvements to public administration (Songsore 2011;Ayee 1996). This did not however dissuade the military government of the Provisional National Defence Council (PNDC) (1981-1993) from promoting decentralisation as a strategy for improving government's response to public demands, promoting service delivery and empowering citizens to participate in decision making (Asante and Ayee 2008; Crook 1994). Although the current local government system owes its existence to the PNDC, some experts observed that decentralisation of power was a condition demanded by the World Bank and the IMF (Oquaye 1995). This condition served a dual purpose because its fulfilment was a prerequisite for the government to receive funds under the economic recovery programme during the 1980s and a means of mitigating legitimacy crises that characterise military regimes (Crook 1994; Ayee 1997). Political and economic 
liberalisation became a key eligibility criterion used by western donors' to push African dictators, including JJ Rawlings, the chairman of the PNDC, on the path of 'good governance' in exchange for financial aid. Consequently, the military government increased the number of local governments from 65 to 110 to demonstrate its commitment to citizens' participation in governance. Rawlings declared that 'Ghana inherited a distorted concept of democracy which concentrated authority solely at the top so that each one of us, individually or collectively, owed everything to the politicians and bureaucrats in Accra. The time has come to give primacy to the local level in the evolution of democracy' (Rawlings 1988).

During that period, certain powers and responsibilities were transferred from central government to lower levels of government including civil servants operating at the local level (Oquaye 1995). Economically, the economy of Ghana witnessed a turnaround from a decline towards growth, as a result of policy initiatives undertaken under the economic recovery and structural adjustment programme. Songsore (2011: 168) reports that real GDP grew at an average of 5\% per year while the rate of inflation fell from $123 \%$ in 1983 to $40 \%$ in 1984 and further to $10 \%$ in 1985 . Local government reforms, downsizing of the public sector and reduction in government expenditure contributed to these achievements but in retrospect, it is unclear why the PNDC military government naïvely considered the new decentralised local government system as an experiment without realising that it would later become the backbone of public administration in Ghana.

Local governments in Ghana are classified on the basis of population size as Metropolitan, Municipal and District Assemblies (MMDAs) even though structures that support local government administration at the sub-national level exist in three distinct vertical layers (Figure 1). The first level comprises Regional Coordinating Councils (RCCs) in each of the 10 administrative regions, entrusted with roles that affect local governance even though the regional administrations do not have the powers of local government authorities. At the sub-regional level, there are 6 Metropolitan Assemblies, 49 Municipal Assemblies and 161 District Assemblies. These Assemblies make up the second tier, and operate on the principle of decentralisation aimed at deepening participatory democracy; coordinating local economic development; addressing national poverty reduction objectives, and recently contributing towards the achievement of the Millennium Development Goals (Satterthwaite 2005; Alam and Koranteng 2011). Below the Assemblies are Sub-metropolitan Councils, Urban, Town and Zonal Councils and Unit Committees at the lowest level. Unfortunately, Unit Committees have lost their relevance, and do not exist in many jurisdictions (Songsore 2011). This has intensified calls for their abolition (Ahwoi 2010). For instance, during local level elections in 2010, there were supposed to be about 16,000 Unit Committees throughout the country but their formation and composition continue to be an enigma. The diagram below depicts the hierarchical structure of Ghana's local government system. 
Figure 1: Structure of local government system in Ghana showing central-local relations (Source: author, 2013)

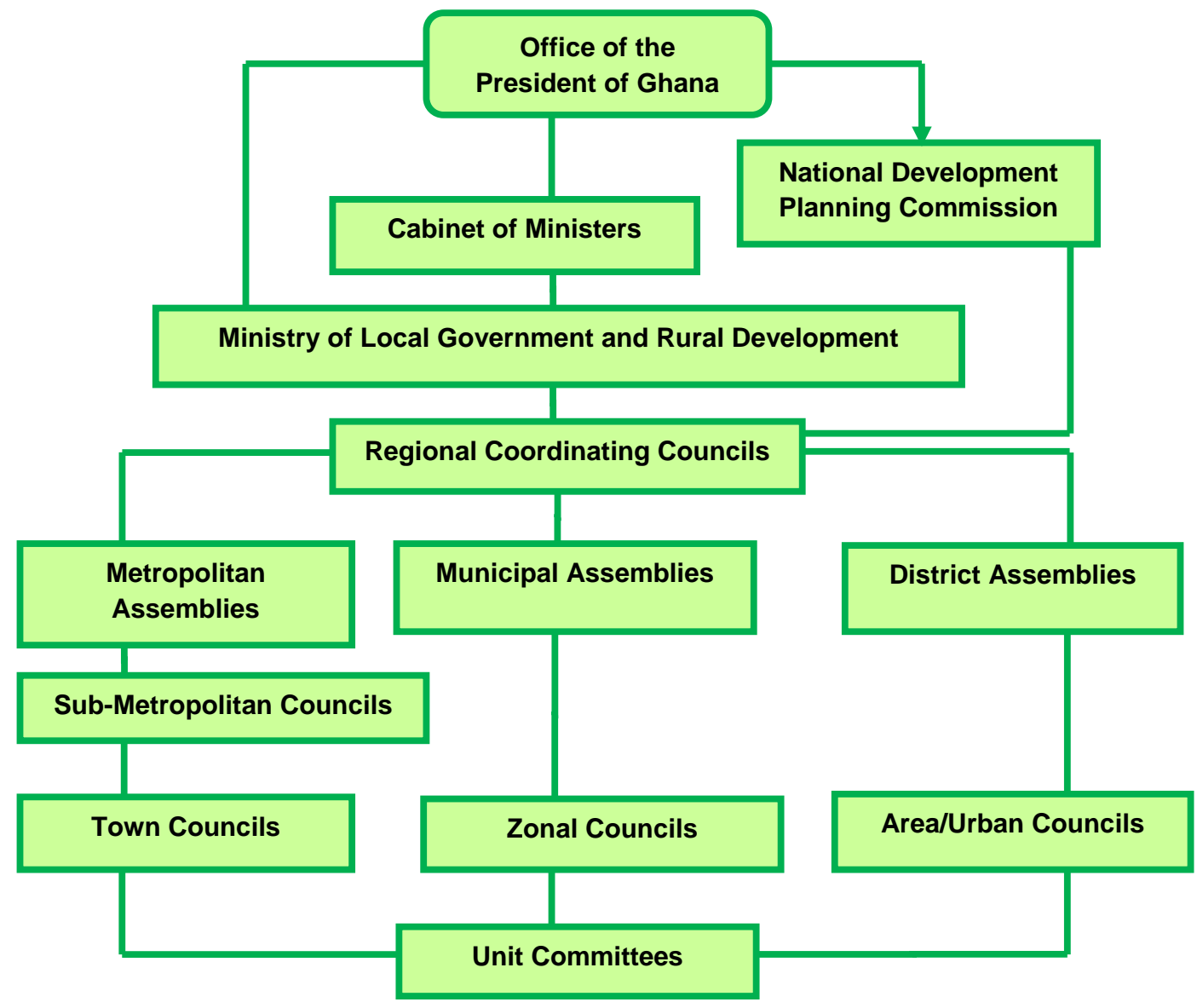

Despite concerns about the limited impact of sub national structures, interests in the performance of local government authorities continue to be driven by constitutional mandates that empower them to facilitate the country's development from a bottom-up perspective. Chapter 20, Article 240 of the Constitution of Ghana unequivocally states that 'Ghana shall have a system of local government and administration which shall, as far as practicable, be decentralised'. This constitutional provision is reinforced by the local Government Act (Act 462) which further defines the powers, scope and functional responsibilities of Metropolitan, Municipal and District Assemblies, which must perform deliberative, legislative and executive functions, obliged to exercise political and administrative authority to provide guidance, give direction to, and supervise other administrative authorities to manage development in the district.

According to the Local Government Act (Act 462), 1993, Assemblies in Ghana:

a) are responsible for the overall development of the district and shall, through the Regional Coordinating Council, ensure the preparation and submission for approval of:

- district development plans to the National Development Planning Commission, and

- the district budget for approved plans to the Minister responsible for Finance;

b) shall formulate and execute plans, programmes and strategies for the effective mobilisation of the resources necessary for the overall development of the district; 
c) shall promote and support productive activity and social development in the district and remove any obstacles to initiative and development;

d) shall initiate programmes for the development of basic infrastructure and provide municipal works and services in the district;

e) are responsible for the development, improvement and management of human settlements and the environment in the district;

f) are responsible for the maintenance of security and public safety in the district; and

g) shall ensure ready access to Courts in the district for the promotion of justice.

However, scholarly assessments of local government performance have presented mixed results. In two separate case studies, Crook (1994) and Ayee (1996) examined changes in administrative performance under the new dispensation of democratic decentralisation. Crook (1994) defined performance as output effectiveness, responsiveness and process acceptability, and found that development output increased marginally when democratic decentralisation was introduced in Ghana even though it failed to respond to citizen's demands. Ayee (1996) focused mainly on the government's core objectives of promoting participation, effectiveness and accountability found that local governance generated a sense of voluntarism as it encouraged a culture of 'self-help' which inspired residents of local communities to take charge of their own development particularly when local governments provided school buildings, electricity, water facilities and roads. After two decades of decentralisation, Ayee and Crooks' description of local government success remains relevant; especially when the performance of local government authorities continues to fall short of citizens' expectations despite the expansion of powers and resources for Assemblies to boost their performance.

There are numerous reasons why many citizens are not enthused about local government performance. At the heart of this discontent is the composition of local government councils. For example, $70 \%$ of Assembly Members (councillors) are elected by universal suffrage every four years with no affiliation to a political party, whilst the remaining $30 \%$ are appointed by the President. A Chief Executive (mayor) is then nominated by the President, who only assumes office after obtaining two-thirds majority votes of all the Assembly Members, present and voting (Ahwoi 2010). The nomination of Metropolitan, Municipal and District Chief Executives (mayors) by the President deprives citizens of the privilege of determining their leader, and this manipulative dominance of the centre over local governments is inimical to local democracy, transparency and accountability in local areas (Ayee and Dickovick 2010; Crook 1994). As political heads, Chief Executives may be influenced by partisan interests even though local governments are supposed to be non-partisan (Songsore 2011). Furthermore, the 30\% of Assembly appointments awarded by the President, contrary to the original purpose of equipping local government authorities with skilled and 
experienced people, are now used to reward political party loyalists without recourse to competence and professional experience (Ayee and Dickovick 2010).

Another reason why local government is considered unimpressive is the inability to provide essential services (Awortwi and Helmsing 2007). To address this problem, a District Assembly Common Fund (DACF) was established to provide financial resources to all local governments (Danquah et al 2013), from a pool fund originally set at 5\% of total government budget until 2007 when it was increased to $7.5 \%$ (Figure 2). Fiscal transfers from the DACF are made to local governments in quarterly instalments to enable them carry out their planned activities. Nonetheless, significant obstacles remain.

Despite the increase in DACF disbursements depicted in Figure 2, local governments have not been able to mobilise sufficient Internally Generated Funds (IGF) to supplement those received from the DACF. There are reports that IGF ranges between 18-30\% of local government revenue even in peak times (Ayee and Dickovick 2010; Osei-Akoto et al. 2007). Few if any local government authorities can survive

Figure 2: The DACF disbursement trend from 1994- 2012

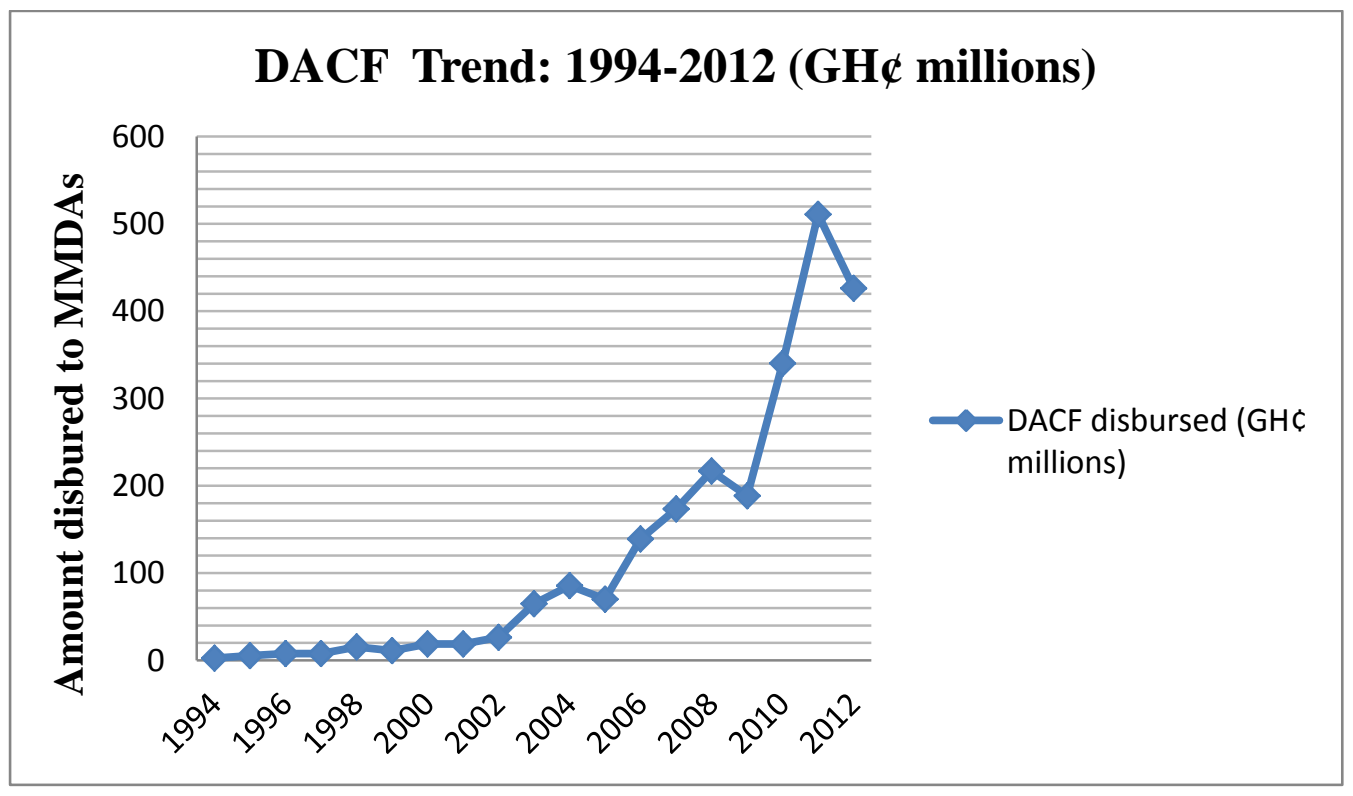

Source: Ministry of Local Government and Rural Development, 2012.

without the DACF because IGF revenue has no promise of making them financially self-sufficient. Many local governments, especially those in rural areas, lack sound economic and commercial tax bases, thereby limiting their sources of revenue.

Limited tax opportunities caused by narrow tax nets and ineffective revenue collection mechanisms raise questions as to whether the economic potential of local governments is sufficiently explored. The ineffectiveness of sub-district structures, especially urban, zonal and town councils also contributes to low revenue mobilisation. Even where sub-district structures carry out revenue 
mobilisation roles delegated to them by parent Assemblies, serious leakages of cash into private pockets occur (Ahwoi 2010; Ayee and Dickovick 2010). It is therefore not surprising that the Auditor General's report, which is prepared annually to cover government ministries, departments and agencies for the Public Accounts' Committee of Parliament, has often raised queries about activities that border on dishonesty, financial mismanagement, or corruption and about the prevalence of administrative cultures that undermine the performance of local governments and development agendas. Apart from placing more emphasis on effective leadership and integrity which are crucial values for managing local governments, punitive measures against people and organisations who misappropriate funds meant for local government authorities leaves much to be desired.

\section{Path dependency: a conceptual overview}

Although path dependency as a concept emerged from literature on market-centred economics and sociology, organisational researchers have often borrowed it to examine the evolution of organisational systems. To Mahoney, 'path dependence characterises specifically historical sequences in which contingent events set into motion institutional patterns or event chains that have deterministic properties' (Mahoney 2000: 507). In this study, path dependency is used metaphorically to analyse administrative practices that may have some historic significance. The underlying thesis of path dependency in organisations suggests that 'history matters', which implies that organisations are carriers of history (David, 1990) and that the essence of history is neither intermittent nor occasional, but remains significant at all times (Sygow \& Schreyo 2009).

Path dependency is built on a number of underlying premises, e.g.: that the timing and sequencing of events matter in policy development; that similar conditions can produce a range of events, and that policy streams or social outcomes may result from relatively 'small' and sometimes unconnected events (Pierson 2000). It is believed that when certain initiatives are set in motion, it becomes difficult for them to be reversed, and that political developments, including policy initiatives are often punctuated by critical moments or junctures which tend to shape the contours of social life (Collier and Collier 1991; Pierson 2000). Nevertheless, there are several opinions on how policy initiatives in organisations are initiated, sustained and eventually become path dependent. Thelen (1999) for instance critiqued path-dependent adherents for failing to specify the mechanisms that translate critical junctures into lasting institutional legacies. To Peters et al (2005), normative institutionalism can explain how values might be sustained, even though such values might only be held by top level management without being shared across different hierarchies within an institution.

Mahoney (2000) observed that scholars have often studied two main strands of path dependent sequencing, self-reinforcing sequences and reactive sequences. Self-reinforcing sequences symbolise chains of events that systematically form and reproduce a long-term institutional pattern. It is believed that organisational actions including policy directives produce self-reinforcing sequences when they 
exhibit what economists call 'increasing returns' (Pierson 2000) and 'positive feedback' (Thelen 1999) obtained through learning and continuous practice. Increasing returns implies that once an institutional practice is adopted, it is expected to deliver increasing benefits when it is uninterrupted. By implication, it becomes more difficult over time to transform the prevailing pattern or select other options even if these would have been more efficient (Pierson 2000; Mahoney 2000). To Thelen (1999), when political organisations find themselves on a particular path, the benefits anticipated by policy makers, interest groups, and other players increase while the costs of shifting to another alternative increases. She attributes path dependency to institutional stickiness in processing inputs into outputs, and cognitive stickiness to decision makers by suggesting that when external pressure is mounted on institutions to change, it may be too late for them to adjust particularly when major punctuations have already occurred. Transposing this argument to the Ghanaian context, it is suggested that decentralisation reforms initiated in 1988 showed signs of both 'institutional and cognitive stickiness' even though policy makers saw the reforms as an experiment rather than making evidence-based adjustments to produce an effective local government system.

Reactive sequences are described as chains of events that are temporarily but causally connected (Mahoney 2000). They are described as 'reactive' on the basis that each event within the sequence is both linked and reacts to previous events such that each step in the sequence is dually 'dependent' on previous and future steps. Analysis that focuses on this type of sequencing considers the final outcome in the chain of events as an important reference largely because the whole spectrum of events is considered as a path leading up to this end.

Another important contribution is the systematic analysis of Sydow and Koch (2009), who proposed three chronological steps for examining organisational path dependency that emphasises the reproduction of self-reinforcing dynamics. The authors suggest that singular historical events can set off self-reinforcing processes which could result in 'organisational lock-in'. Thus, all the three phases are governed by dependent causal linkages, but also exert different effects on organisational actions and decision making (Pierson 2000).

In Sydow and Koch's analysis, the first step known as the pre-formation phase consists of a repertoire of options that define plausible scopes of action. While Mahoney (2000:511) suggests that the effect of a choice of action when selected at this stage is uncertain, Sydow and Koch agree with Pierson (2000) that irrespective of the wide range of options in this phase, a policy choice may emerge from a small event that unintentionally sets off a self-reinforcing process. These noticeable moments or shifts that resonate in a self-reinforcing process are the critical junctures (Collier and Collier 1991) which indicate the end of the pre-formation phase.

The second phase, known as the formation phase, represents a stage where the pattern of dominant action eventually emerges and shows signs of irreversibility. With time, the scope of policy options 
narrows, making it difficult to reverse the preferred choice. This signifies the evolution of a path. The last phase is referred to as the lock-in phase, and stands out as the stage where alternative options are further narrowed, eventually resulting in the institutionalisation of organisational norms, practices or policies. Thus practices, policies and values become fixed to a known path that is believed to be linked to an aspired goal. At this stage, one particular policy choice becomes predominant and flexibility can be severely compromised.

Collier and Collier (1991) highlight the reproduction of institutional legacies associated with critical junctures and the duration of such legacies. They compared how legacies were created and reproduced in Mexico and Brazil. By analysing labour relations, they showed how the Institutional Revolutionary Party; Partido Revolucionario Institucional (PRI), a left-wing party in Mexico, used state resources to establish its hegemony over labour at all levels, producing a legacy of labour relations based on patronage such that working class people who felt they owed their jobs to the PRI also felt responsible for sustaining that legacy. This form of labour inclusion directly contrasted with Brazil where labour relations were suppressive and intimidating; reproducing a legacy of labour alienation and exclusion. Some critical junctures produce stable regimes whereas others tend to be obstructive in nature (Collier and Collier 1991: 34).

As Thelen (1999) noted it is thus important for researchers to identify the factors (events and processes) that undermine legacies. In Collier and Collier's study (1991), the friendly space offered to labour in Mexico, even though it became poisoned with patronage, encourages acceptance and institutionalisation of government employment policy, contrary to Brazil where no such space gained the commitment of labour. Yet, even though the critical junctures literature has relevance for the analysis of policy evolution, timing, and chronology at national and supra-national (macro) levels, it tends to overlook local level factors that could be instrumental in sustaining legacies. By referring to the implementation of decentralisation reforms in Ghana, it can be argued that successive governments have responded differently to critical junctures. Central government has persistently used local governments to mobilise support for political gains rather than strengthening local government authorities to promote socioeconomic development. Despite the re-establishment of democratic and constitutional governance in 1992, central government still appoints Chief Executives (mayors) for local government authorities. This is a serious drawback because their unelected status weakens mechanisms for transparency and downward accountability which has severe repercussions for local government performance.

\section{The trail of MMDA performance assessment: design or accident?}

Two recent applications of path-dependent analysis in Ghana illuminate the evolution and punctuations in policy formulation that shape the structure of government machinery. One deals with civil service and central management agencies whilst the other focuses on decentralisation (Awortwi 
2011; Ohemeng and Anebo 2012). Although the studies are laudable in navigating the historic path of public sector reforms in Ghana, they delved little into the performance of local government authorities - the gap this paper fills.

There is no doubt that local governance was given a new lease of life in 1988 when the new local government law, PNDCL 207 was passed. This was significant because intermittent political instabilities triggered by military coups had disabled the implementation of any meaningful public sector reform (Ayee, 1997). The promulgation of PNDCL 207 was followed by the demarcation of geographic boundaries that increased the number of local government authorities from 65 to 110 . From 1982 when the PNDC government declared its vision of decentralisation in an 11-point decentralisation programme (Mohan 1996) to 1993 when the Local Government Act (Act 462), 1993, was enacted under the 1992 Constitution, there was still no holistic examination of the performance of local government authorities, despite their long existence. None of the possible methods of assessing the performance of local governments had ever been fully utilised. The Ministry of Local Government and Rural Development (MLGRD) and the National Development Planning Commission (NDPC) on behalf of central government only seek to monitor the formulation and implementation of local governments' Medium Term Development Plans (MTDPs) as a way of assessing performance. Regional Coordinating Councils (RCCs) have also monitored the planning processes of local governments for almost two decades, but the effectiveness of these evaluations on local government performance remains an open question.

Today, the normative practice of assessing local government performance is practically embedded in the relationship between the central government in Accra and local government authorities in the 10 regions of Ghana. The unequal nature of that relationship inevitably undermines the Assemblies' autonomy, given that their plans, programmes and projects must correspond with national development priorities set by central government, defined by the National Development Planning Commission which is part of the executive arm of government. As the agency responsible for advising the president on matters of development planning, policy and strategy, the NDPC is enjoined by the National Development Planning [Systems] Act, (1994) Act 480 to coordinate the performance of local government authorities. This legislation laid the path for implementing a nationwide decentralised planning system that is monitored at the regional level by the RCCs and coordinated and supervised at the centre by the NDPC.

Within the past two decades of the Commissions' existence, it has developed four different national development strategies each of which has attempted to achieve the same objective of development in Ghana. The first national development strategy under the current decentralisation system was the Ghana Vision 2020, which aimed to transform Ghana into a middle income country by the year 2020 . 
Unfortunately, it was truncated in 2001 when the NPP (New Patriotic Party) replaced the NDC (National Democratic Congress) after the 2000 election.

The replacement national development plan was the Ghana Poverty Reduction Strategy (GPRS I) published in 2003; its main goal was to ensure sustainable equitable growth, accelerated poverty reduction and the protection of the vulnerable and excluded within a decentralised, democratic environment' (NDPC 2003:30). This was replaced in 2005 by the Growth and Poverty Reduction Strategy (GPRS II), which sought to accelerate economic growth and achieve the status of a middleincome country within the planning period. After the 2008 presidential and parliamentary elections, the NDC assumed office again, and formulated a new national development framework known as the Ghana Shared Growth and Development Agenda (GSGDA) to advance its 'better Ghana Agenda'. These 'agenda-setting' strategies are implemented by Ministries, Departments and Agencies (MDAs) at the national level, RCCs at the regional level and the Metropolitan, Municipal and District Assemblies at the local level, and thus the GSGDA (2010 to 2013) represents the first phase of a coordinated programme which:

forms the basis for the preparation of development plans and annual budgets at the sector and district levels throughout the country(Government of Ghana 2010)

While central government considers nationwide implementation of the national development plan as a means of achieving government priorities, this encumbrance deprives local government of concentrating on local development challenges. The MMDAs' development plans and operational activities are expected to reflect the objectives of national development policy, and the 10 RCCs play a crucial role in making this happen. They monitor the utilisation of funds allocated to local government authorities by central government; review and co-ordinate public services and monitor, co-ordinate and evaluate the performance of local governments in the regions. These tasks are expected to be accomplished through regular and periodic visits to local government areas where ongoing projects are monitored. However, nationally set targets have become difficult for local governments to meet because targets are broad, generic and macro in nature. Instead of taking the contexts of different local governments into consideration, the current GSGDA considers oil and gas exploration as one of its key focal areas although few local governments are endowed with oil and gas resources. In addition, while RCCs undertake performance monitoring of local governments such inspections often target physical infrastructure projects such as school building, health facilities, feeder roads, sanitation and electrification projects. This reduces the notion of development to the availability of physical infrastructure, but the RCCs seem to have no alternative in reviewing, harmonising and forwarding performance progress reports of all local governments in their regions to the NDPC.

While this practice is the institutionalised mechanism by which local government performance has been evaluated for two decades, it not evident that it has actually improved the performance of local 
governments in Ghana. The effectiveness of monitoring and evaluating local governments' performance by the RCCs is constrained by persistent lack of funds for regular monitoring. Apart from depending entirely on central government transfers, the RCCs' lack of power to generate revenue coupled with the erratic and irregular grant disbursement further worsens their predicament.

What seems puzzling is the inability of the NDPC to differentiate 'star' performers from 'poor' performers although the RCCs have monitored local governments for two decades. Assuming the NDPC could make such a distinction, there is no incentive to motivate any hypothetical 'star' performers, nor would the NDPC be able to sanction local governments that performed poorly or flouted the NDPC's guidelines. In spite of increases in the volume and scope of financial resources available to local governments, most of them continued to perform their core functions rather unsatisfactorily (Crook 1994; Ayee 1997). A critical juncture was therefore reached in the mid-2000s which required politicians and policy makers to react to find alternative ways of assessing local government performance, which coincided with the period when the DACF, the largest grant to local governments, was increased from $5 \%$ to about $7.5 \%$ of total government revenue, leading donor agencies to lobby central government to demand value for money and exact accountability from local governments in the utilisation of funds.

\section{Are local governments en route to performance improvement?}

In 2008, the Government of Ghana introduced an initiative to improve the performance of local governments, particularly with respect to efficiency, accountability, and the provision of basic essential services. Central to this initiative is a Performance Based Grant (PBG), known as the District Development Facility (DDF).

The DDF is a fund established by the Government of Ghana supported by the Canadian International Development Agency (CIDA), Danish International Development Agency (DANIDA), the German Development Bank (KFW) and the French Development Agency (AFD). The DDF makes funds available to local governments that comply with rules, regulations and policies linked to the performance of their mandates. This has become a vital source of additional funds for them to plan, undertake or implement development projects and programmes. However, Assemblies only receive funds from the DDF after their performance had been assessed by consultants to the Ministry of Local Government and Rural Development (MLGRD), using performance indicators embodied in a diagnostic instrument, the Functional Organisational Assessment Tool (FOAT). This tool also identifies capacity gaps that impede the Assemblies performance to justify why some local governments may need capacity-building support.

The assessment, is conducted annually, and is intended to ensure that local governments comply with existing legal and regulatory frameworks linked to the administration of their areas. As a result, the 
evaluation criteria are largely driven by statutory obligations and functional responsibilities assigned to the Assemblies by the Local Government Act (Act 462), 1993, and other local governance statutes. Thus the performance indicators are derived from the core functions of local government authorities which capture a variety of internal organisational processes, but are less effective in monitoring service delivery (output/outcome) variables.

Meanwhile, the link between FOAT and the DDF is fundamental to understanding how the performance of local government authorities is assessed, and the basis on which financial reward is given. Since this mechanism was the first of its kind introduced to benchmark local government performance in Ghana, its implementation can be described as experimental. This has led to revisions of the formulae and key performance indicators to reflect current local government needs. The evaluation tool is structured around two sets of indicators classified as Minimum Conditions (MCs) and Performance Measures (PMs). In parallel, allocation of funds under the DDF is categorised into three components: a basic grant consisting of $20 \%$ of the total amount of funds in a given fiscal year, a $68 \%$ performance grant and a $12 \%$ capacity building grant.

In 2011, the Ministry of Local Government with the support of the World Bank used the existing assessment template to launch a new project known as the Local Government Capacity Support Project (LG-CSP). An Urban Development Grant (UDG) was introduced as part of this project to provide financial incentives to urban local governments based on their performance. The grant is intended to support local governments in urban areas deal with contemporary challenges of urbanisations including urban poverty and growing infrastructure needs.

During the annual assessments, local governments that obtain higher scores by fulfilling most of the minimum condition indicators and performance measures receive more financial reward than their counterparts. The minimum conditions involve a set of issues local governments must meet in order to access the basic grant under the DDF, which focus on:

- Development planning

- Financial management and accounting

- Public procurement

- Implementation capacity and

- The general functioning of the local government authority

Fulfilling the minimum conditions means that local governments must demonstrate:

- the existence of functional district planning and coordinating units;

- availability of financial statements and audit reports devoid of adverse comments, and the preparation of procurement plans (Government of Ghana 2012); 
- that at least three General Assembly (council) meetings have been held within the year under review;

- the formulation of Medium Term Development Plans and annual action plans, and

- must submit progress reports that reflect the implementation of development plans to RCCs (for harmonisation).

Unlike the minimum conditions, performance measures are structured into nine thematic areas that local governments must fulfil in order to qualify for performance grants under the DDF. Apart from these performance indicators, Metropolitan and Municipal Assemblies are further assessed for the UDG using five main indicators. Each indicator is assigned a weighted value based on which performance scores are awarded during the assessment. Table 1 shows performance measures and maximum weight used in the FOAT and the urban development grant.

Table 1: Weights of performance measures in FOAT and UDG

\begin{tabular}{llccc}
\hline & Performance measures in the FOAT & $\begin{array}{c}\text { Maximum } \\
\text { score }\end{array}$ & $\begin{array}{c}\text { Performance measures } \\
\text { under UDG }\end{array}$ & $\begin{array}{c}\text { Maximum } \\
\text { score }\end{array}$ \\
\hline $\mathbf{1}$ & Management and organisation & 10 & Budgeting & 15 \\
$\mathbf{2}$ & Transparency, openness and Accountability & 12 & Reporting and auditing & 15 \\
$\mathbf{3}$ & Planning system & 16 & Asset management & 20 \\
$\mathbf{4}$ & Human resource management & 7 & Revenue management & 35 \\
$\mathbf{5}$ & Relationship with sub-structures & 6 & Social accountability & 15 \\
$\mathbf{6}$ & Financial management and auditing & 16 & Total & $\mathbf{1 0 0}$ \\
$\mathbf{7}$ & Fiscal capacity & 15 & & \\
$\mathbf{8}$ & Procurement & 12 & & \\
$\mathbf{9}$ & Environmental sanitation management & 6 & & \\
& Total & $\mathbf{1 0 0}$ & &
\end{tabular}

Source: MLGRD: DDF Operational Manual (2012)

The table above categorises performance measures that qualify local governments for DDF funds and the UDG. While these measures highlight key areas upon which local governments are assessed to determine whether they qualify for performance-based grants, those that are unable to qualify are provided with a CBG (Capacity Building Grant) so $12 \%$ of the DDF fund is set aside as capacitybuilding grant payable to local governments that do not qualify for any of the other grants. Local governments that receive the capacity-building grant are required to train staff in specific areas that were identified during the assessment. The identification of capacity gaps is followed by training programmes proposed by the assessment teams to the Ministry of Local Government for approval. From these trainings, local s officials are expected to equip enhance their performance in subsequent assessments.

Perhaps to demonstrate its commitment and ownership of the local government performance assessment initiative, the Government of Ghana has been the highest contributor to DDF funds. However, it is quite obvious especially after the creation of new local government authorities that the 
Government of Ghana would have faced serious implementation difficulties without the financial support and technical assistance of the four DDF development partners, and other donors may soon be contributing to the DDF. The quest to continue supporting the initiative can be traced to potential gains made by Assemblies that have benefited from the fund; for example, out of a total of 138 Assemblies that were evaluated in 2008, 50 of them fulfilled all the minimum conditions whilst 88 Assemblies failed. This means than majority of the Assemblies were only eligible for the CBG (12\% of DDF); depriving them of the performance grant (68\% of DDF) that could have been invested to improve infrastructure in local communities. Figure 3 below indicates scheduled contributions made by the Government of Ghana and development partners to the DDF so far.

Figure 3: Contributions to the DDF, 2009 - 2012

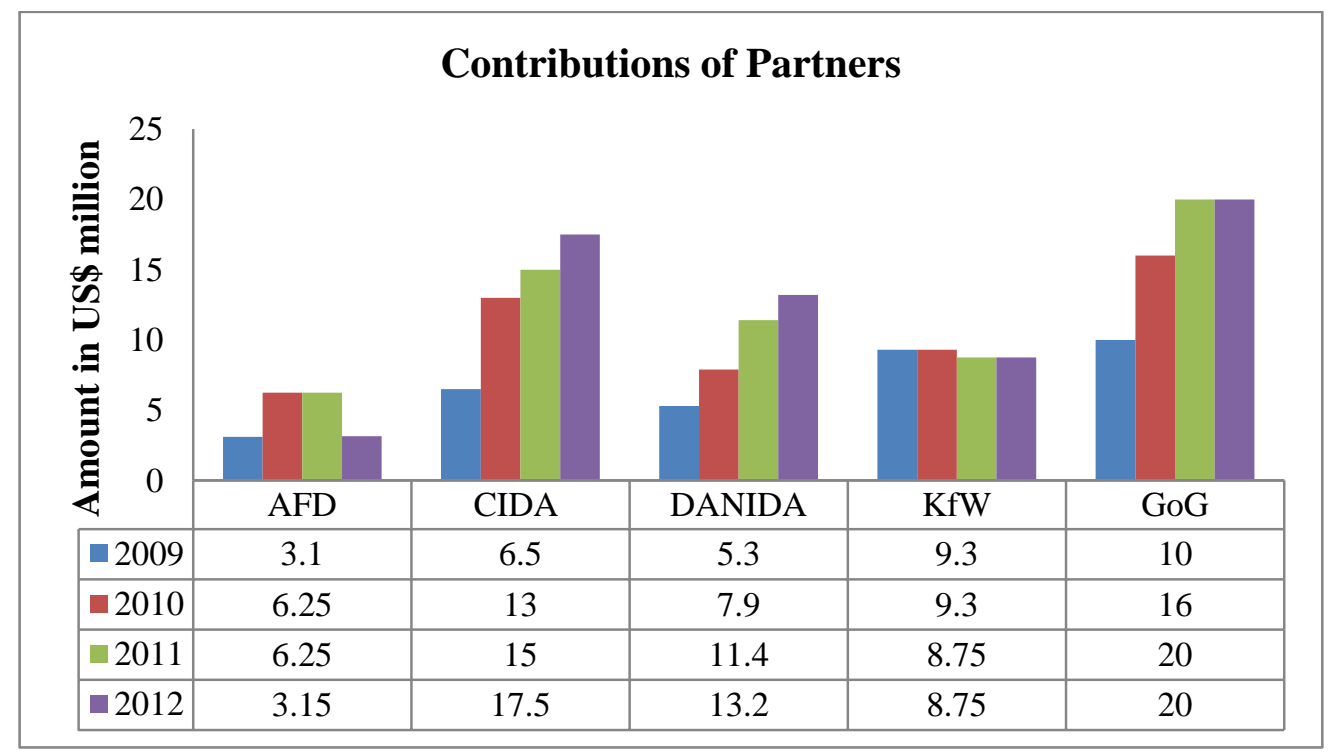

Source (AfD, 2013).

After the first DDF funding round, local governments used the capacity building grant to train their staff, and in the second round only 37 local governments failed to fulfil the minimum conditions, despite the creation of 32 new districts. It is obvious that the DDF seeks to reduce local governments' over-dependence on what has become an overburdened and unpredictable DACF.

The additional funds received by local government authorities under the DDF vary, ranging from US\$ 31.9 million disbursed in 2008; US\$ 56.4 million in 2009; $\$ 44,495,300$ in 2010 ; to US\$ 135,564,800 in 2011 respectively. The most recent performance assessment was completed in the last quarter of 2012, and performance scores are yet to be published. Despite these assessments, there is still no database to affirm whether local governments have used the additional funds to improve service delivery. Furthermore, one wonders whether the regulations are not just another means by which central government uses bureaucratic procedures to control local government authorities rather than addressing the most pertinent interest of local governments which is serving local communities. 


\section{Missing links and forgotten factors: towards a people-centred approach}

The paper highlights various initiatives by successive governments to promote local government performance. It is however obvious that none of these initiatives was created by local government authorities themselves. It is therefore not surprising that ordinary citizens in local communities, who are arguably more suitable to determine the performance of their local government councils, do not have a voice in assessing local governments' performance. However, would have thought that due to divergent perspectives of what constitutes organisational performance, a more balanced or multidimensional approach should have been adopted to embrace other key aspects of performance assessment.

This argument is laid on the foundation that citizens' perceptions form a crucial part in how governments perform. For many people, appreciating local government performance will depend on the extent to which political promises as well as pledges of development are fulfilled in terms of the quantity and quality of government output, and whether outcomes such as value for money and citizen satisfaction are guaranteed (Yang and Rho 2007), which has given impetus to the use of citizen surveys in assessing government performance (Behn 2003).

Measurement of satisfaction data provides feedback to government because the concerns of citizens can be used to hold governments accountable to the public (Wholey and Hatry 1992; Roch and Poister 2006). A notable example is the Afro-barometer which uses surveys to mobilise public opinion about government performance. Another commendable initiative is the district oversight committee concept that was introduced by the Governing Council of the Africa Peer Review Mechanism (GC-APRM) in Ghana. Members of these committees represent different interests groups who receive hands-on training to undertake satisfaction surveys. This helps them to elicit popular opinion about local government performance based on the four key themes of the APRM (Democracy and Good Political Governance; Economic Governance and Management; Corporate Governance and Socio-economic Development). Such surveys are capable of equipping local governments with information that clarify public aspirations and expectations which the former could use to sharpen their processes, policies and programmes to improve the quality of services (Howard 2010). Perceptions about citizen's satisfaction can serve as indicators for determining the publics' trust in government and can possibly be used as a proxy measure of good governance (Bouckaert and van de Walle 2003; Yang and Holzer 2006).

\section{Conclusion}

Clearly, the decentralised local government experiment that started two decades ago in Ghana has come to stay. Thus local government authorities will forever be expected to perform their constitutionally mandated tasks effectively and efficiently, but local government autonomy is 
compromised by central-local government relations that continue to shape national policies and local agendas, leaving local government to fulfil dual objectives of satisfying both local communities and central government. In reality, the implementation of policies has been evolutionary, sometimes resulting in punctuations and critical junctures that call for ways of improving the system. The collaboration between the Government of Ghana and development partners to improve local government performance has sound objectives but raises questions over whether mechanisms are in place to maximise their developmental impact. Performance-based grants have significantly supported local governments in providing basic social infrastructure and building the capacity of local government employees to enhance their performance. Yet, from a path-dependent perspective, the performance of local government authorities did not take centre stage at the onset of local government reforms because the government was interested in meeting conditions for donor assistance rather than building and strengthening local institutions. For this reason, assessing the performance of local government in a systemic manner seems to have been an afterthought that focuses on administrative procedures rather than the core business of serving local communities. Even though central-local government interactions promote some performance monitoring of local government authorities, the practice whereby Regional Coordinating Councils collate and forward local government plans and performance reviews to the centre leaves much to be desired. It is unclear why the experimental attitude towards local government reforms neither embedded nor institutionalised citizen-led performance assessment into the new local government system.

We concur that fixing institutional fault lines in the operation of local government authorities is a potential entry-point in order to identify alternatives that might improve the developmental role of sub national governments (de Visser 2009). Whilst the existence of fault lines may not imply that a particular policy initiative is inherently ineffective, analysing them could help to address operational bottlenecks that inhibit the success of development policies, which is crucial in Ghana where local government performance is a priority amongst ordinary people, donor agencies and central government. A balanced and consensual approach in the assessment of local government performance is important. Des and Robinson (1984) suggests that for organisational performance to be clarified and made easier, performance assessment mechanisms must create consensus amongst relevant stakeholders over what performance entails. This suggestion is however not easy to implement because the scope of local government performance is broad and embroiled in serious political discourses that makes it difficult to agree on what performance entails (Brewer and Selden 2000). To Boyne (2002), judging local government performance in terms of outputs, efficiency, effectiveness, responsiveness, or other democratic outcomes would be driven by the interests of whoever is evaluating performance, reinforcing the subjectivity in how performance is sometimes perceived. Hence, portraying local government performance assessments in Ghana as an objective process may be illusive especially when it fails to integrate citizens' opinions. 


\section{References}

Ahwoi, K. (2010). Local Government and Decentralization in Ghana: Unimax Macmillan.

Alam, M. \& Koranteng, R. (2011). Decentralisation in Ghana: Papers presented at workshops held at GIMPA, Ghana from 2007-2010. London: Commonwealth Secretariat

Asante, F. \& Ayee, J. R. A. (eds.) (2008). Decentralization and Poverty Reduction’ London: James Currey.

Awortwi, N. (2011). An unbreakable path? A comparative study of decentralization and local government development trajectories in Ghana and Uganda. International Review of Administrative Sciences, 77(2), 347377.

Awortwi, N. \& Helmsing, A. H. J. (2007). Governance of basic services provision in sub-Saharan Africa and the need to shift gear.

Ayee, J. \& Dickovick, J. T. (2010). Comparative Assessment of Decentralization in Africa: Ghana Desk Study. Report prepared for the United States Agency for International Development. Contract: DFD-I- 00-04-0022700. United States Agency for International Development (USAID).

Ayee, J. R. A. (1996). The Measurement of Decentralization: The Ghanaian Experience, 1988-92. African Affairs, 95(378), 31-50.

Ayee, J. R. A. (1997). The Adjustment of Central Bodies to Decentralization: The Case of the Ghanaian Bureaucracy. African Studies Review, 40(2), 37-57.

Behn, R. D. (2003). Why Measure Performance? Different Purposes Require Different Measures. Public Administration Review, 63(5), 586-606.

Bouckaert, G. \& Halligan, J. (2008). Managing Performance: International Comparisons. London: Routledge.

Bouckaert, G. \& van de Walle, S. (2003). Comparing Measures of Citizen Trust and User Satisfaction as Indicators of 'Good Governance': Difficulties in Linking Trust and Satisfaction Indicators. International Review of Administrative Sciences, 69(3), 329-343.

Boyne, G. A. (2002). Concepts and indicators of local authority performance: An evaluation of the statutory frameworks in England and Wales. Public Money and Management, 22(2), 17-24.

Brewer, G. A. \& Selden, S. C. (2000). Why Elephants Gallop: Assessing and Predicting Organizational Performance in Federal Agencies. Journal of Public Administration Research \& Theory, 10(4), 685.

Collier, R. B. \& Collier, D. (1991). Shaping the Political Arena: Critical Junctures, the Labor Movement, and Regime Dynamics in Latin America. . Princeton, NJ: Princeton University Press.

Crook, R. C. (1994). Four years of the Ghana district assemblies in operation: Decentralization, democratization and administrative performance. Public Administration and Development, 14(4), 339-364.

Danquah, N. Y. B., Sakyi, E. K. \& Appiah-Agyekum, N. N. (2013). Local Government Finance in Ghana: Disbursement and Utilisation of the MP's share of the District Assemblies Common Fund. Commonwealth Journal of Local Governance, (12).

de Bruijn, H. (2002). Managing performance in the public sector. London: Routledge.

de LancerJulnes, P. \& Holzer, M. (2001). Promoting the Utilization of Performance Measures in Public Organizations: An Empirical Study of Factors Affecting Adoption and Implementation. Public Administration Review, 61(6), 693-708.

de Visser, J. (2009). Developmental Local Government in South Africa: Institutional fault lines. Commonwealth Journal of Local Governance, (2).

Government of Ghana (2010). Medium-Term National Development Policy Framework: Ghana Shared Growth and Development Agenda (GSGDA)- 2010-2013 In: National Development Planning Commission (NDPC) (ed.).

Government of Ghana (2012). Operational Manual for the implementation and administration of the District Development Facility. In: Ministry of Local Government and Rural Development (MLGRD) (ed.). Accra.

Halligan, J., Bouckaert, G. \& Dooren, W. V. (2010). Performance Management in the Public Sector: Routledge. Howard, C. (2010). Are we being served? A critical perspective on Canada's Citizens First satisfaction surveys. International Review of Administrative Sciences, 76(1), 65-83.

Kaplan, R. S. \& Norton, D. P. (1992). The Balanced Scorecard--Measures That Drive Performance. Harvard Business Review, 70(1), 71-79. 
Kaplan, R. S. \& Norton, D. P. (2000). The Strategy-Focused Organization: How Balanced Scorecard Companies Thrive in the New Business Environment. Boston, MA: Harvard Business School Press.

Lawton, A., McKevitt, D. \& Millar, M. (2000). Developments: Coping with Ambiguity: Reconciling External Legitimacy and Organizational Implementation in Performance Measurement. Public Money \& Management, 20(3), 13-20.

Mahoney, J. (2000). Path dependence in historical sociology. . Theory and Society, 29(4), 507-548.

Meyer, M. W. (2002). Rethinking Performance Measurement. Cambridge: Cambridge University Press.

Mohan, G. (1996). Neoliberalism and decentralised development planning in Ghana. Third World Planning Review, 18(4), p.433.

NDPC (2003). Ghana Poverty Reduction Strategy: Analysis and Policy Statement. In: National Development Planning Commission (ed.).

OECD (1997). Managing across Levels of Government Paris: OECD.

Ohemeng, F. K. \& Anebo, F. K. (2012). The Politics of Administrative Reforms in Ghana: Perspectives from Path Dependency and Punctuated Equilibrium Theories. International Journal of Public Administration, 35(3), $161-176$

Oquaye, M. (1995). Decentralisation and development: The Ghanaian case under the provisional national defence council (PNDC). The Journal of Commonwealth \& Comparative Politics, 33(2), 209-239.

Osei-Akoto, I., Osei, R. D., Quarmine, W. \& Adiah, G. A. N. (2007). Public spending at the district level in Ghana. Ghana Strategy Support Program (GSSP) Background Paper No. GSSP 0008

Peters, B. G., Jon, P. \& King, D. S. (2005). The Politics of Path Dependency: Political Conflict in Historical Institutionalism. The Journal of Politics, 67(4), 1275-1300.

Pierson, P. (2000). Increasing Returns, Path Dependence, and the Study of Politics. The American Political Science Review, 94(2), 251-267.

Rawlings, J. J. (1988). Picking Up the Pace of Progress: Selected Speeches of Flt. Lt. J.J. Rawlings, Chairman of the P.N.D.C: Information Services Department Press.

Roch, C. H. \& Poister, T. H. (2006). Citizens, Accountability, and Service Satisfaction. Urban Affairs Review, 41(3), 292-308.

Sanderson, I. (2001). Performance Management, Evaluation and Learning in 'Modern' Local Government. Public Administration, 79(2), 297-313.

Satterthwaite, D. (2005). Meeting the MDGs in urban areas: the forgotten role of local organizations. Journal of International Affairs, 58(2), 107-112.

Songsore, J. (2011). Regional development in Ghana: the theory and the reality: Woeli Pub. Services.

Sotirakou, T. \& Zeppou, M. (2006). Utilizing performance measurement to modernize the Greek public sector. Management Decision, , 44(9), 1277 - 1304.

Sydow, J., SchreyÖGg, G. \& Koch, J. (2009). ORGANIZATIONAL PATH DEPENDENCE: OPENING THE BLACK BOX. Academy of Management Review, 34(4), 689-709.

Sygow, R. J. \& Schreyo, G. G. (2009). Organizational Path Dependence: Opening the Black Box. Academy of Management Review34(4).

Talbot, C. (2010). Theories of Performance: Organisational and service improvement in the public domain: Oxford University Press.

Thelen, K. (1999). Historical Institutionalism in Comparative Politics. Annual Review of Political Science, 2(1), 369.

Thomas, G. P. (2006). Performance Measurement, Reporting, Obstacles and Accountability recent Trends and Future Directions. In: University, A. N. (ed.). University Printing Services.

Wholey, J. S. \& Hatry, H. P. (1992). The Case for Performance Monitoring. Public Administration Review, 52(6), 604-610.

Yang, K. \& Holzer, M. (2006). The Performance-Trust Link: Implications for Performance Measurement. Public Administration Review, 66(1), 114-126.

Yang, K. \& Rho, S.-Y. (2007). E-Government for Better Performance: Promises, Realities, and Challenges. International Journal of Public Administration, 30(11), 1197-1217. 